\title{
Analysis of the pterygopalatine fossa in patients undergoing surgically-assisted rapid maxillary expansion: a morphometric study using cone beam
}

\author{
Análise da fossa pterigopalatina em pacientes submetidos à expansão maxilar rápida assistidla \\ cirurgicamente: um estudo morfométrico utilizando a tomografia computadorizada de feixe cônico \\ Análisis de la fosa pterigopalatina en pacientes sometidos a expansión maxilar rápida asistida \\ quirúrgicamente: estudio morfométrico mediante TC de haz cónico
}

Received: 09/08/2021 | Reviewed: 09/11/2021 | Accept: 09/14/2021 | Published: 09/16/2021

Isabella Maria Zanutto

ORCID: https://orcid.org/0000-0001-5341-8257 State University of Maringa, Brazil

E-mail: zanutto.isa@gmail.com

Liogi Iwaki Filho

ORCID: https://orcid.org/0000-0001-9117-6826

State University of Maringa, Brazil

E-mail: liogifilho@gmail.com

Breno Gabriel da Silva

ORCID: https://orcid.org/0000-0002-8322-9235

University of São Paulo, Brazil

E-mail: brenogsilva@usp.br

Mariliani Chicarelli da Silva

ORCID: https://orcid.org/0000-0002-0024-7471

State University of Maringa, Brazil

E-mail: mchicarelli1@gmail.com

Elen de Souza Tolentino

ORCID: https://orcid.org/0000-0002-4352-4694

State University of Maringa, Brazil

E-mail: elentolentino83@gmail.com

Eder Alberto Sigua-Rodriguez

ORCID: https://orcid.org/0000-0002-7971-9856

University Institution Colleges of Colombia, Colombia

E-mail: edersiguaodont@gmail.com

Lilian Cristina Vessoni Iwaki

ORCID: https://orcid.org/0000-0002-1822-3056

State University of Maringa, Brazil

E-mail: lilianiwaki@gmail.com

\begin{abstract}
This retrospective, observational, longitudinal study performed a morphometric analysis of the pterygopalatine fossa (PPF) in patients undergoing surgically assisted rapid maxillary expansion (SARME) using cone beam CT (CBCT). CBCT scans of 41 consecutive patients were assessed and the following measurements were performed: PPF volume (PPFV), height (PPFH), length (PPFL) and angle (PPFA). The sample was divided into groups D (patients undergoing SARME; $n=26)$ and control ( $n=15)$. Group D was subdivided into D+ (with pterygomaxillary disjunction - PMD) and D- (without PMD). The differences between the pre and postoperative periods were tested using the U Mann-Whitney or the t-test. Groups D+ and D- were compared using the one-way ANOVA or Kruskal-Wallis tests (level of significance set at 5\%). In general, there were morphometric variations in PPF, with lower values after SARME. Differences for PPFH, PPFL and PPFA were not significant $(p>0.05)$. On the right side, there were differences in PPFV, with lower values in patients from group $\mathrm{D}+(\mathrm{p}<0.05)$. These findings indicate a morphometric reduction of PPF after SARME, with differences when the disjunction is performed or not. The maxillofacial surgeon must be aware of these changes when performing SARME with or without disjunction.
\end{abstract}

Keywords: Pterygopalatine fossa; Radiology; Cone beam computed tomography; Palatal expansion technique.

\section{Resumo}

Este estudo retrospectivo, observacional e longitudinal realizou uma análise morfométrica da fossa pterigopalatina (PPF) em pacientes submetidos à expansão maxilar rápida assistida cirurgicamente (SARME) utilizando TCFC (TCFC). Foram avaliadas tomografias CBCT de 41 pacientes consecutivos e foram realizadas as seguintes medições: 
Volume de PPF (PPFV), altura (PPFH), comprimento (PPFL) e ângulo (PPFA). A amostra foi dividida em grupos D (pacientes submetidos à SARME; $n=26)$ e controle $(n=15)$. O grupo $\mathrm{D}$ foi subdividido em $\mathrm{D}+$ (com disjunção pterigomaxilar - PMD) e D- (sem PMD). As diferenças entre o período pré e pós-operatório foram testadas usando o U Mann-Whitney ou o teste t. Os grupos D+ e D- foram comparados usando os testes ANOVA ou Kruskal-Wallis unidirecionais (nível de significância fixado em 5\%). Em geral, houve variações morfométricas no PPF, com valores mais baixos após a SARME. As diferenças para PPFH, PPFL e PPFA não foram significativas ( $>00,05)$. No lado direito, houve diferenças no PPFV, com valores mais baixos em pacientes do grupo $\mathrm{D}+(\mathrm{p}<0,05)$. Estes achados indicam uma redução morfométrica de PPF após a SARME, com diferenças quando a disjunção é realizada ou não. O cirurgião maxilofacial deve estar ciente destas mudanças ao realizar a SARME com ou sem disjunção.

Palavras-chave: Fossa pterigopalatina; Radiologia; Tomografia computadorizada de feixe cônico; Técnica de expansão palatina.

\section{Resumen}

En este estudio retrospectivo, observacional y longitudinal se realizó un análisis morfométrico de la fosa pterigopalatina (PPF) en pacientes sometidos a una expansión maxilar rápida asistida quirúrgicamente (SARME) mediante TC de haz cónico (CBCT). Se evaluaron las exploraciones de CBCT de 41 pacientes consecutivos y se realizaron las siguientes mediciones: Volumen de PPF (PPFV), altura (PPFH), longitud (PPFL) y ángulo (PPFA). La muestra se dividió en los grupos D (pacientes sometidos a SARME; $n=26)$ y control $(n=15)$. El grupo D se subdividió en $\mathrm{D}+$ (con disyunción pterigomaxilar - PMD) y D- (sin PMD). Las diferencias entre los periodos pre y postoperatorio se comprobaron mediante la prueba U de Mann-Whitney o la prueba t. Los grupos D+ y D- se compararon mediante las pruebas ANOVA de una vía o Kruskal-Wallis (nivel de significación fijado en el 5\%). En general, hubo variaciones morfométricas en la PPF, con valores más bajos después de la SARME. Las diferencias para la PPFH, la PPFL y la PPFA no fueron significativas (p>0,05). En el lado derecho, hubo diferencias en la PPFV, con valores más bajos en los pacientes del grupo D+ $(\mathrm{p}<0,05)$. Estos hallazgos indican una reducción morfométrica de la FPP después de la SARME, con diferencias cuando se realiza la disyunción o no. El cirujano maxilofacial debe ser consciente de estos cambios al realizar la SARME con o sin disyunción.

Palabras clave: Fosa pterigopalatina; Radiología; Tomografía computarizada de haz cónico; Técnica de expansión palatina.

\section{Introduction}

The pterygopalatine fossa (PPF) is an anatomical structure with pyramidal shape and an inverted base (Tashi et al., 2016), located between the viscerocranium and the neurocranium. It communicates with the orbit through the inferior orbital fissure; with the middle cranial fossa through the foramen rotundum and the pterygoid canal; with the nasopharynx through the pharyngeal canal; with the infratemporal fossa through the pterygomaxillary fissure; with the nasal cavity through the sphenopalatine foramen; and with the oral cavity through the greater palatine foramen and lesser palatine foramina (Derinkuyu et al., 2017). PPF is considered an important neurovascular bone conduit (Evans et al., 2016), where the maxillary nerve and its pharyngeal branches, greater and lesser petrosal nerves, maxillary artery, Vidian and sphenopalatine arteries are interconnected (Evans et al., 2016, Derinkuyu et al., 2017).

PPF has been studied by several medical specialties (Liu et al., 2017; Gibelli et al., 2019) since the region represents the access for endoscopic surgeries on the skull. This is a surgical challenge, since it is a very innervated and vascularized region (Afieri et al., 2003; Elhadi et al., 2016; Gibelli et al., 2019). Morphometric studies in macerated skulls (Codari et al., 2016), by endoscopy (Yushkevich et al., 2006) and computed tomography (CT) (Yushkevich et al., 2006) allowed a better anatomical mapping of this region. More recently, the cone beam CT (CBCT) has also been considered for the study of this region, as it allows accurate measurements with lower radiation doses compared to helical CT (Icen \& Orhan, 2019).

In oral and maxillofacial surgery, PPF is directly accessed in surgically-assisted rapid maxillary expansion (SARME) procedures. Considering that approximately $9.4 \%$ of the population has posterior crossbite and that this number increases to $30 \%$ in patients who require orthognathic surgery (Bailey et al., 2001), SARME is often indicated, especially when skeletal maturity has been reached or in cases of severe unilateral or bilateral maxillary transverse hypoplasia (Han et al., 2009). SARME provides adequate correction of transverse discrepancies such as increased lower anterior facial height and unaffected palate height after SARME. Arch depth can be an important indicator to predict stability after expansion (Sockucu et al., 
2009). In SARME, performing the pterygomaxillary disjunction (PMD) is optional. The indication of PMD and its postoperative clinical implications are discussed in the literature. Some authors (Carvalho et al., 2019) report that not performing PMD can increase the chances of postoperative complications, for example. There are no studies assessing the morphology of PPF after SARME with or without PMD. Then, the aim of this study is to perform a morphometric analysis of the PPF in patients undergoing SARME, using CBCT. The null hypothesis is that there are no morphological changes in PPF in patients undergoing SARME.

\section{Methodology}

\subsection{Study design}

After approval of the local Ethics Committee for Research Involving Human Beings (CAAE 34234020.0.0000.0104), this retrospective, observational, longitudinal study was developed according to STROBE (Strengthening the Reporting of Observational Studies in Epidemiology) initiative (Von Elm et al., 2008).

\subsection{Sample reliability}

CBCT scans of 41 consecutive patients who underwent examination at the Oral Radiology Clinic between September 2017 and December 2019 were assessed. The sample size was similar to that of Medeiros et al. (2017), who assessed the effects of SARME on the airways $(n=25)$. Patients of both sexes older than 18 years were included. The sample was divided into two groups: (D) intervention $(n=26)$; and $(C)$ control $(n=15)$. Patients from group $D$ were diagnosed with maxillary atresia (> 5mm) and used Hyrax expanders (supervised by the same team of orthodontists) prior to SARME. All surgical procedures were performed by a same team of experienced surgeons (UEM). Group D (underwent to SARME) was subdivided into groups D+ (with PMD) and D- (without PMD). As it is a convenience sample (not probabilistic) (Kish, 1995), exclusion criteria were not applied to the intervention group. The control group included class I patients ( $8 \mathrm{men} ; 7$ women) without congenital or acquired craniofacial deformities, history of trauma or previous surgery in the region. The selection of these patients was random.

\subsection{SARME procedure}

A horizontal incision was performed $3 \mathrm{~mm}$ above the mucogingival junction bilaterally, from the zygomatic pillar to the canine region. Then, the mucoperiosteal detachment was performed, exposing the entire maxillary lateral wall, from the piriform aperture to the maxillary tuberosity. An Obwegeser ramus retractor was inserted through a subperiosteal tunnel along the maxillary posterolateral wall towards the posterior region and another retractor was positioned for tissue retraction. The lateral wall and the mucosa of the nasal floor were detached and carefully lifted. A thin and malleable blade (Quinelatoß Schobell Industrial Ltda., Rio Claro, SP, Brazil) was inserted in the lateral region to prevent perforation during osteotomies, which were carried out under constant irrigation with saline solution. In the D+ group, the Le Fort I osteotomy was performed $5 \mathrm{~mm}$ above the dental apexes, from the piriform aperture to the maxillary tuberosity bilaterally.

A small vertical incision of the mucosa was made in the anterior region of the median palatal suture. Vertical osteotomy was performed between the upper central incisors affecting only the buccal cortex. Then, a fine chisel was inserted into the suture just below the anterior nasal spine with a slight angle to the bottom. The index finger of the opposite hand was used under the palatal region and the chisel was tapped gently until it reached the palatal portion. To achieve separation of the posterior nasal spine, the chisel was repositioned in a more horizontal position and tapped about $30 \mathrm{~mm}$. The diastema was observed and mobilized with a Sverzut retractor, confirming the maxillary disjunction. Then, the incisions were sutured with resorbable thread. 


\subsection{Hyrax expander}

The Hyrax expander started to be activated seven days after surgery (Alves et al., 2017; Findik et al., 2019), using the following protocol for all patients: $2 / 4$ turn $(0.50 \mathrm{~mm})$, twice a day, with a $13 \mathrm{~mm}$ expansion screw. After reaching the planned expansion, the devices were blocked and maintained for six months to maintain the expansion until definitive ossification (Findik et al., 2019; Kaylar et al., 2019). The expander was cemented on the dental bands on the first premolars and first molars, a few days before surgery.

\subsection{Image acquisition}

All patients undergoing SARME followed the same protocol: they underwent CBCT before surgery (T1) and 6 months postoperatively (T2). All scans were obtained in the Next Generation ${ }^{\circledR}$ i-Cat equipment (Imaging Sciences International), with $120 \mathrm{Kvp}, 3-8 \mathrm{~mA}, 17 \mathrm{X} 23 \mathrm{~cm}$ FOV and $0.3 \mathrm{~mm}$ isometric voxel. The DICOM (Digital Imaging and Communication in Medicine) files were imported into ITK-SNAP® 3.6.0 (open-source software available in http://www.itksnap.org) or InVesalius® 3.1 .1 software (open-source software available in https://www.cti.gov.br/ptbr/invesalius).

\subsection{Reliability and Reproducibility}

The images were analyzed by two independent examiners, both experienced, calibrated radiologists, blind to the patient's identification details. All analyzes were performed in a quiet, dark room, and the use of tools such as magnification, brightness and contrast were allowed (Icen \& Orhan, 2019). Before the analyses, all images were reoriented positioning the Frankfort plane parallel to the horizontal plane, in the sagittal reconstruction. To avoid eye fatigue, only 10 images/day were evaluated, and in $100 \%$ of the sample, the measurements were repeated. T1 and T2 images were evaluated by both examiners twice, with an interval of 15 days between evaluations, to establish intra- and inter-examiner agreement. Before the measurements, the examiners were calibrated by reproducing the measurements in 20 exams. After this calibration step, the images were discarded and measurements and data collection were started. All standards and measurements were replicated in group C.

\subsection{Morphometric analysis of PPF}

All variables were measured in PPF bilaterally in groups D + and D- (in T1 and T2) and in group C. PPF volume (PPFV) was assessed using semi-automatic segmentation (ITK-SNAP®). As a reference for the supero-posterior limit, the posterior wall of the maxillary sinus, pterygoid process of the palatal bone, and foramen rotundum were used. For the anterolateral limit, the medial and lateral pterygoid laminae, and the perpendicular lamina of the sphenoid bone. The lower limit was the opening of the greater palatine foramen (Gibelli et al., 2019). The segmentation tool was used to highlight only the bone tissue, and then the bubbles device were added to give volume and contour to the PPF. The growth of bubbles is stopped manually when the established limits are reached, thus forming the three-dimensional structure of the PPF (Figure 1). 
Research, Society and Development, v. 10, n. 12, e158101220388, 2021

(CC BY 4.0) | ISSN 2525-3409 | DOI: http://dx.doi.org/10.33448/rsd-v10i12.20388

Figure 1. Semi-automatic segmentation of the PPF. Visualization of the three planes (axial, coronal and sagittal) and reconstruction of the segmented model (ITK-SNAP® 3.6.0 software).
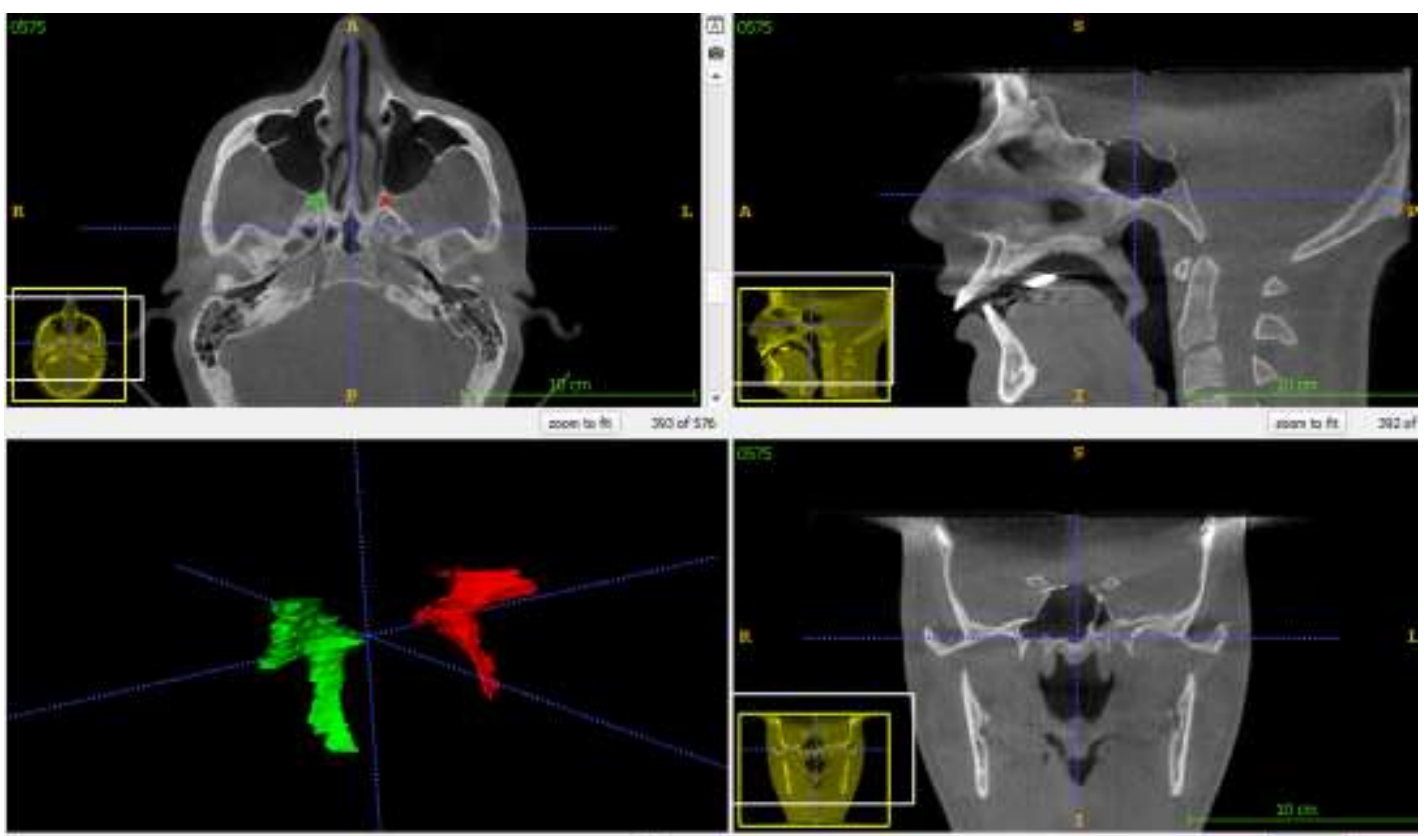

Source: The authors.

The following linear measurements (figure 2) were performed in the sagittal views: PPF height (PPFH) - from the most upper point to the lowest point of the PPF; PPF length (PPFL) - from the most anterior point to the most posterior point of the PPF (Tomaszewska et al., 2015; Vuksanovic-Bozaric et al., 2018).

Figure 2. Linear measurements (in mm) of PPF (sagittal reconstruction): PPF height (red line) and PPF length (green line).

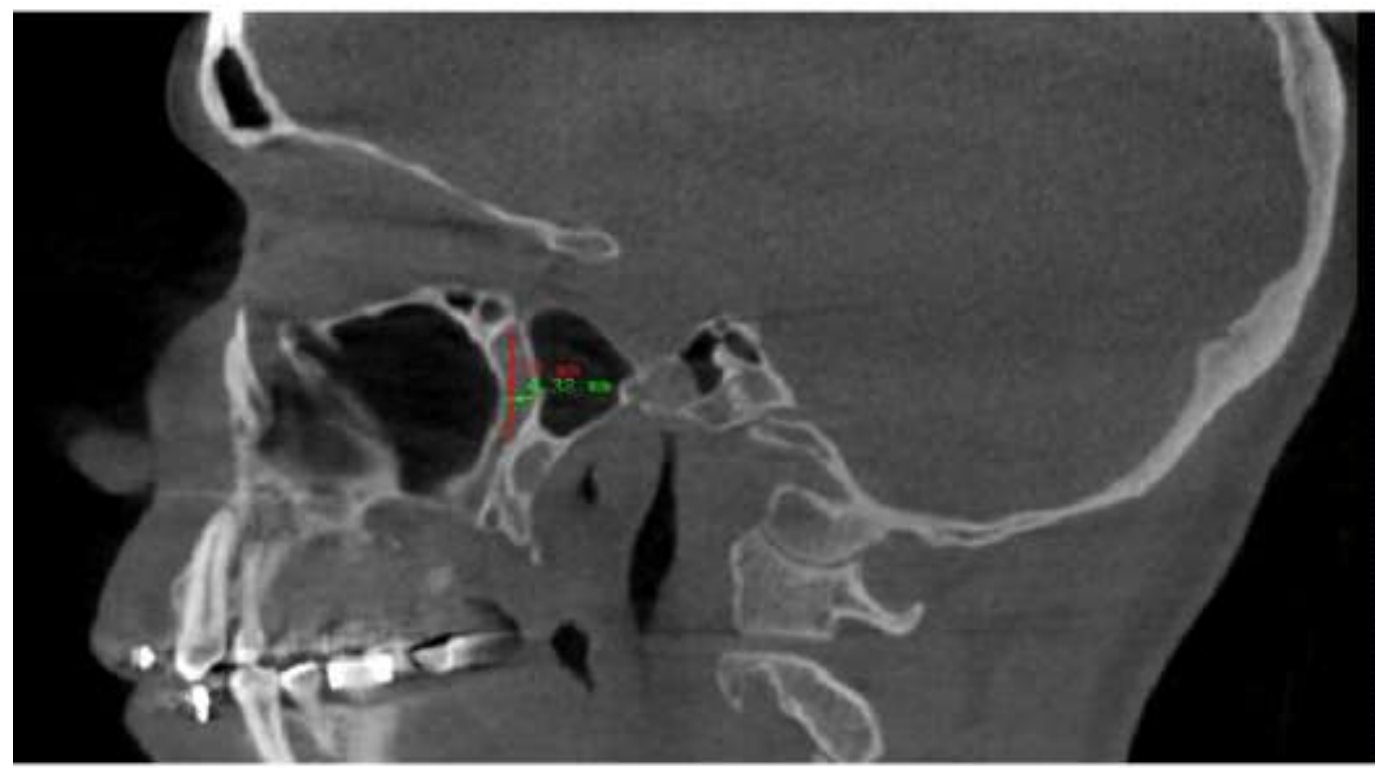

Source: The authors.

Angular measurements were performed in the InVesalius® software (Hasan et al., 2016), in sagittal reconstructions, 
Research, Society and Development, v. 10, n. 12, e158101220388, 2021

(CC BY 4.0) | ISSN 2525-3409 | DOI: http://dx.doi.org/10.33448/rsd-v10i12.20388

using the skull base line (formed by the point that passes through the skull base - foramen magnum - until the meeting of the lesser wing of sphenoid bone with the frontal sinus) and the axial line of the PPF as references (Figure 3). The intersection of the two lines formed the angle of the PPF (PPFA) (Figure 4).

Figure 3. Reference lines for PPF angular measurements (sagittal reconstruction): skull base line (orange) and axial line of PPF (blue) (InVesalius® software).
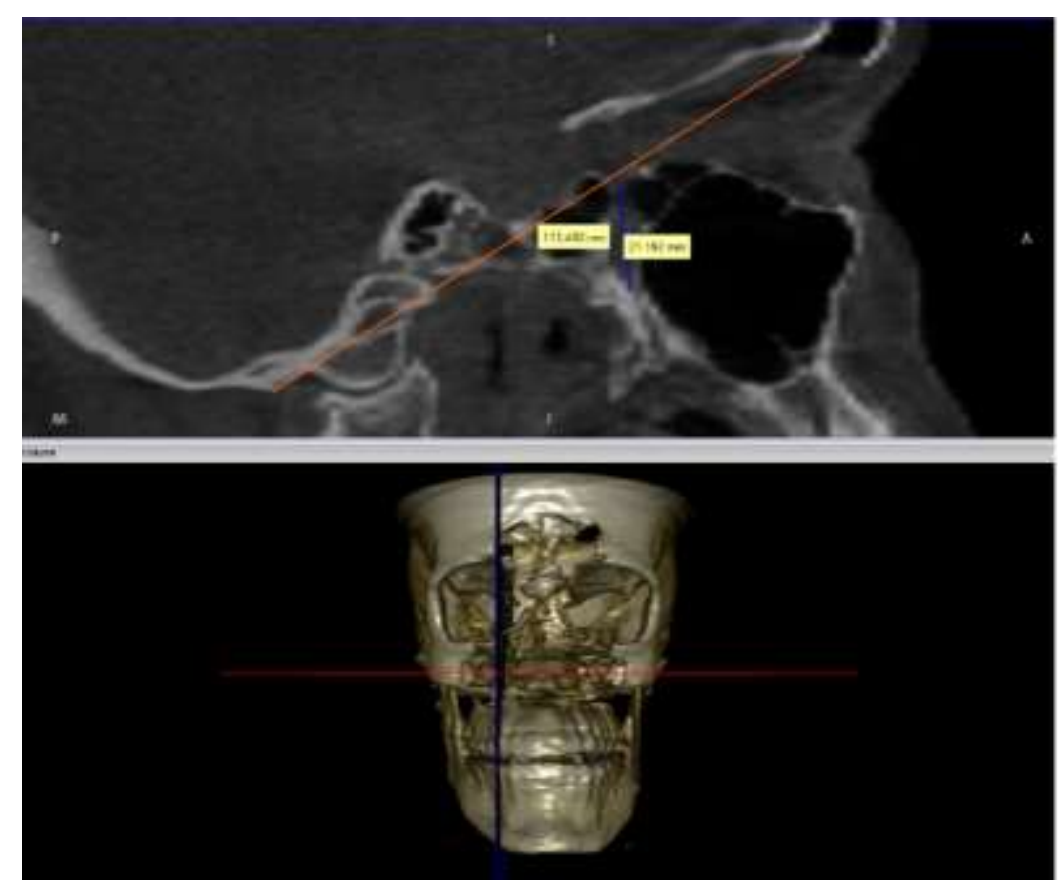

Source: The authors. 
Figure 4. PPF angular measurement $\left(^{\circ}\right)$ (pink): intersection of the skull base line (orange) and the axial line of the PPF (blue) (sagittal reconstruction; InVesalius® software).

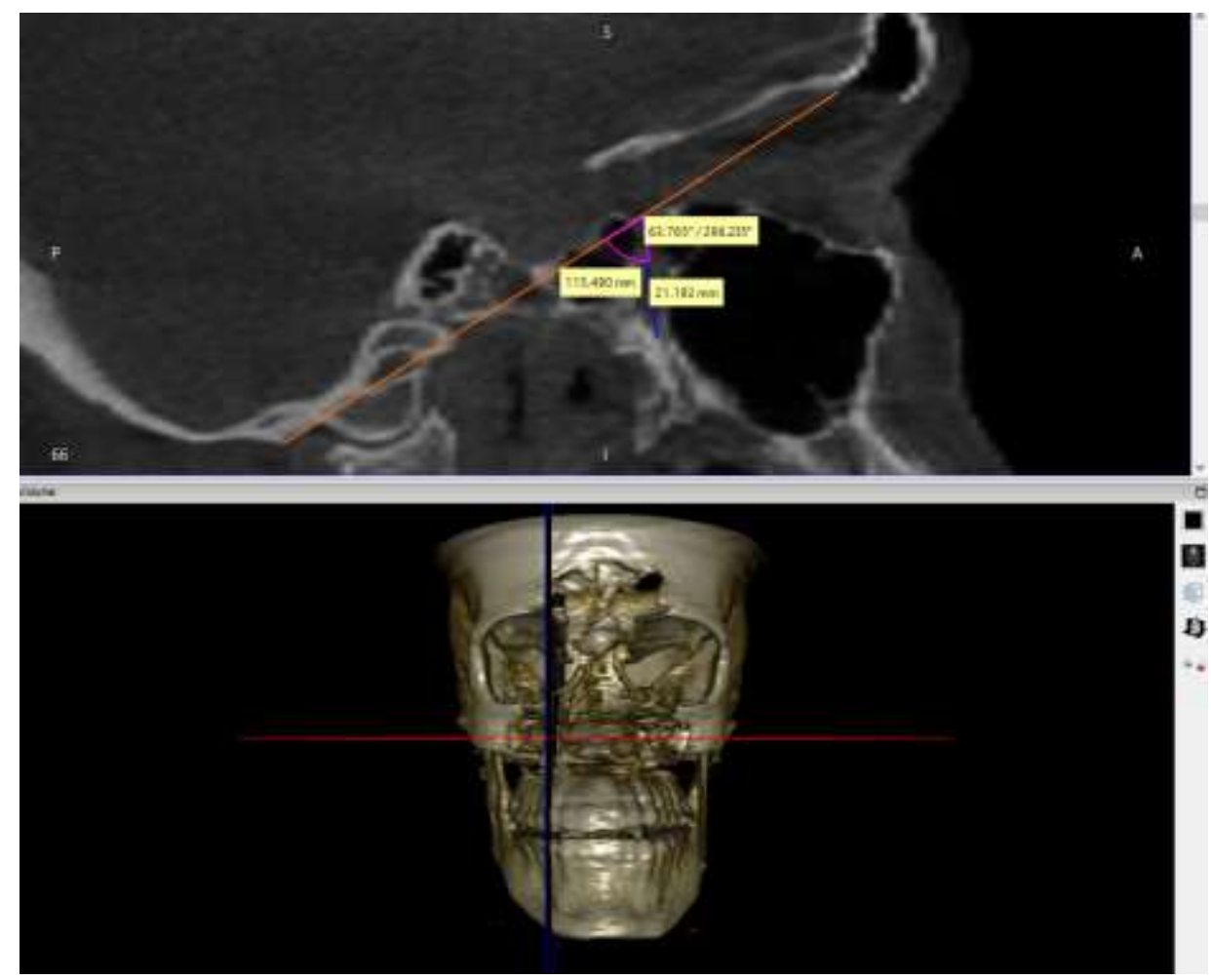

Source: The authors.

\subsection{Data analysis}

All data were analyzed using software $\mathrm{R}$ version 4.0.2 ( $\mathrm{R}$ Core Team. 2020). The graphics were made using the "ggplot2" package (Wickham H. 2016). The intra and inter-examiner concordances were tested with the intraclass correlation coefficient (ICC) using the "irr" package (Gamer M. 2010). The normality assumption for the variables PPFV, PPFH, PPFL and PPFA was investigated using the Shapiro-Wilk test. The differences in these measurements between T1 and T2 in each side and between sides were tested using the t-test (when normality assumption was not violated) or the U Mann-Whitney test (when normality assumption was violated). Groups D+ and D- were compared using the one-way ANOVA (normality assumption not violated) or Kruskal-Wallis (normality assumption violated) tests. When there was significance in the one-way ANOVA test, the Tukey HSD test was also applied. In all tests, the level of significance was set at 5\% (p-value <0.05).

\section{Results}

Of the 41 patients analyzed, 24 (58.53\%) were women and 17 (41.47\%) men, aged between 18 and 64 years (mean $33.19 \pm 12.74)$. In men, the mean age was 31.52 years $( \pm 13.05)$ and in women 34.37 years $( \pm 12.66)$. Regarding the facial skeletal pattern, $12(29.26 \%)$ patients were class I, 19 (46.34\%) class II and 10 (24.39\%) class III. The null hypothesis that intra-examiner agreement is purely random was rejected for all variables, considering both sides and surgical techniques (p $<0.05$ ), and ICC for intra and inter-examiner concordance ranged from 0.87 to 0.99 (Landis \& Koch, 1977). On the left side, greater variability in PPFV was observed in group D+, while on the right side, variability in PPFV was greater in the control group. PPFH showed results opposite to those found in PPFV. For PPFL and PPFA, greater variability was observed in group 
D- in both sides. These results are shown in figure 5 .

Figure 5. Boxplots of the variables volume, height, length and angle in groups D +, D- and C.
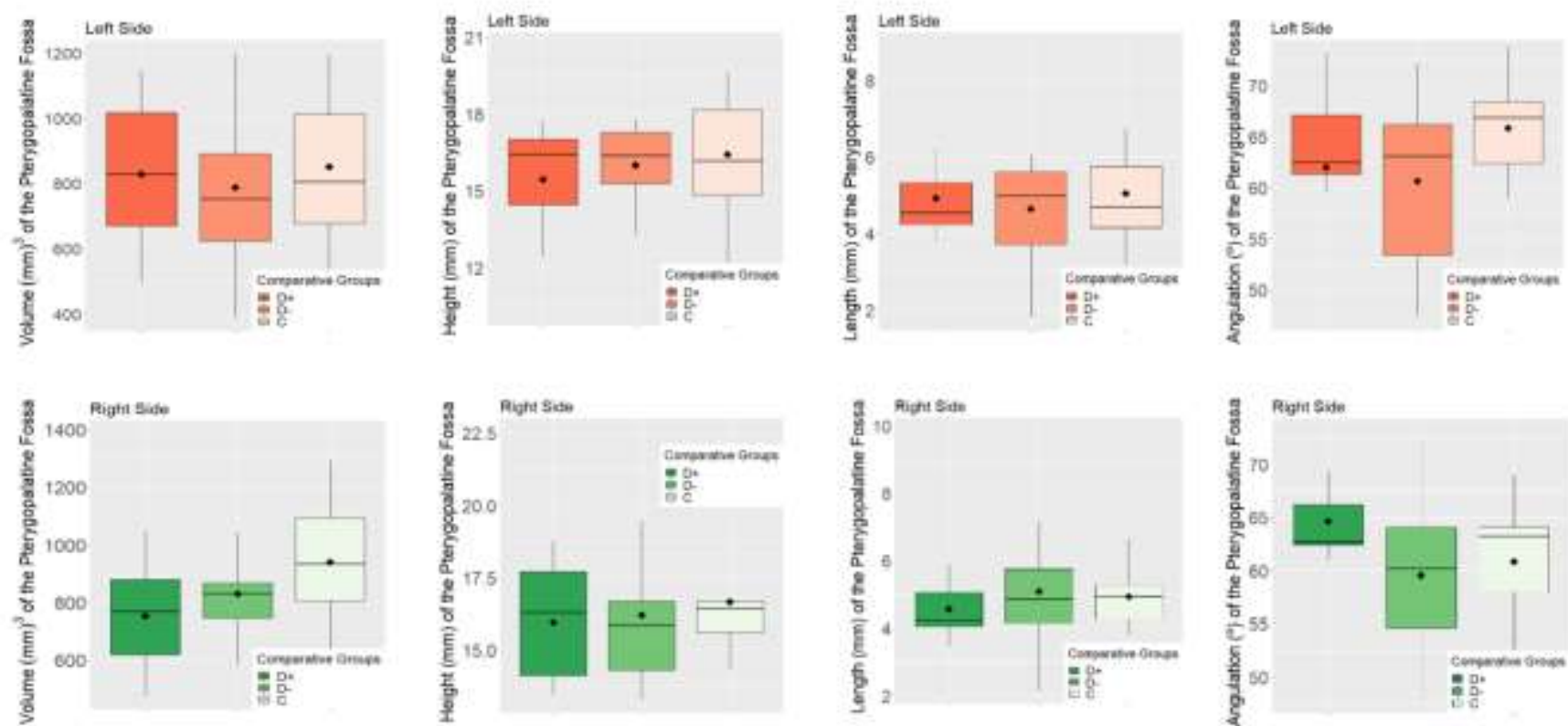

Source: The authors.

The hypothesis of normality was rejected for the variables PPFH and PPFL on the right side in T2, PPFA on both sides in T2 and PPFH of the T1 ( $\mathrm{p}<0.05)$. There were no significant differences between T1 and T2 for PPFV, PPFH, PPFL and PPFA on both sides ( $>>0.05)$. However, all of these variables had higher mean and median values at T1 on both sides (table 1).

Table 1. Comparison of the means and medians of measurements between $\mathrm{T}_{1}$ and $\mathrm{T}_{2}$ on each side.

\begin{tabular}{|c|c|c|c|c|}
\hline \multirow{2}{*}{ Variables } & \multicolumn{2}{|l|}{ Left } & \multicolumn{2}{|l|}{ Right } \\
\hline & Summary measures & $\mathrm{p}$-value & Summary measures & p-value \\
\hline \multirow{2}{*}{ PPFH (mm) } & $16.49(10.21-21.79)^{\dagger \mathrm{T} 1}$ & \multirow{2}{*}{$0.62^{2}$} & $16.38(12.65-22.75)^{\dagger \mathrm{T} 1}$ & \multirow{2}{*}{$0.84^{2}$} \\
\hline & $16.38(10.24-20.66)^{\dagger \mathrm{T} 2}$ & & $16.03(13.29-22.54)^{\dagger \mathrm{T} 2}$ & \\
\hline \multirow{2}{*}{ PPFL (mm) } & $4.92(3.71 \pm 6.13)^{\mathbf{\bullet T} 1}$ & \multirow{2}{*}{$0.84^{1}$} & $4.98(2.69-8.64)^{\dagger \mathrm{T} 1}$ & \multirow{2}{*}{$0.96^{2}$} \\
\hline & $4.86(3.59 \pm 6.12)^{-\mathrm{T} 2}$ & & $4.83(2.15-9,85)^{\dagger \mathrm{T} 2}$ & \\
\hline \multirow{3}{*}{$\operatorname{PPFV}\left(\mathrm{mm}^{3}\right)$} & $823.35(587.20 \pm 1059.49)^{-\mathrm{T} 1}$ & \multirow{2}{*}{$0.98^{1}$} & $849.99(637.05 \pm 1062.92)^{{ }^{\mathrm{T} 1}}$ & \multirow{2}{*}{$0.71^{1}$} \\
\hline & $822.53(605.67 \pm 1039.38)^{-\mathrm{T} 2}$ & & $830.82(624.03 \pm 1037.61)^{-\mathrm{T} 2}$ & \\
\hline & $64.92(48.10-76.68)^{\dagger \mathrm{T} 1}$ & & $63.29(51.20-74.68)^{\dagger \mathrm{T} 1}$ & \\
\hline $\operatorname{PPFA}\left({ }^{\circ}\right)$ & $63.12(47.36-73.17)^{\dagger \mathrm{T} 2}$ & $0.25^{2}$ & $62.49(47.88-73.03)^{\dagger \mathrm{T} 2}$ & $0.36^{2}$ \\
\hline
\end{tabular}

${ }^{1} \mathrm{t}$-Student test; ${ }^{2}$ Mann-Whitney test; ${ }^{\dagger}$ median (min.-max.); "mean ( \pm standard deviation). Source: The authors.

There were no statistically significant differences between the postoperative periods $\left(T_{2}\right)$ on the left and right sides regarding the variables: PPFV, PPFH, PPFL, PPFA ( $p>0.05$ ). However, PPFV had higher means on the right side and PPFH, PPFL, PPFA had higher means on the left side. In both sides, PPFV, PPFH, PPFL, PPFA presented higher mean and median values in group $\mathrm{C}$ (table 2). When comparing these measures among groups D+, D- and C, for PPFV, on the right side, the values in group $\mathrm{D}+$ presented significant differences when compared to $\mathrm{D}$ - and $\mathrm{C}(\mathrm{p}<0.05)$. 
Table 2. Comparison of the means and medians of measurements between groups D +, Dand $\mathrm{C}$ in the postoperative period.

\begin{tabular}{ccccc}
\hline \multirow{2}{*}{ Variables } & \multicolumn{2}{c}{ Left side } & \multicolumn{2}{c}{ Right side } \\
\cline { 2 - 5 } & Summary measures & p-value & Summary measures & p-value \\
\hline \multirow{2}{*}{ PPFH $(\mathrm{mm})$} & $15.45^{\mathrm{D}+}$ & & $16.03^{\mathrm{D}+}$ & \\
& $16.08^{\mathrm{D}-}$ & $0.56^{1}$ & $15.86^{\mathrm{D}-}$ & $0.76^{2}$ \\
& $16.42^{\mathrm{C}}$ & & $16.30^{\mathrm{C}}$ & \\
\hline \multirow{2}{*}{ PPFL $(\mathrm{mm})$} & $4.92^{\mathrm{D}+}$ & & $4.23^{\mathrm{D}+}$ & $0.57^{2}$ \\
& $4.63^{\mathrm{D}-}$ & $0.68^{1}$ & $4.85^{\mathrm{D}-}$ & \\
& $5.04^{\mathrm{C}}$ & & $4.86^{\mathrm{C}}$ & $0.04^{1 *}$ \\
PPFV $\left(\mathrm{mm}^{3}\right)$ & $829.36^{\mathrm{D}+}$ & & $752.65^{\mathrm{D}+} \mathrm{b}$ & \\
& $787.89^{\mathrm{D}-}$ & $0.72^{1}$ & $871.14^{\mathrm{D}-} \mathrm{a}$ & $0.11^{2}$ \\
\hline \multirow{2}{*}{ PPFA $\left({ }^{\circ}\right)$} & $852.16^{\mathrm{C}}$ & & $94.21^{\mathrm{C}} \mathrm{a}$ & \\
& $61.91^{\mathrm{D}+}$ & & $62.10^{\mathrm{D}+}$ & \\
& $63.08^{\mathrm{D}-}$ & $0.17^{2}$ & $60.21^{\mathrm{D}-}$ & $62.70^{\mathrm{C}}$ \\
\hline
\end{tabular}

*Statistically significant; ${ }^{1}$ One-way ANOVA test; ${ }^{2}$ Kruskal-Wallis test; ${ }^{\mathrm{D}+}$ With pterygomaxillary disjunction; ${ }^{\mathrm{D}}$ Without pterygomaxillary disjunction; ${ }^{\mathrm{C}}$ Control-group. Distinct letters (PPFV, right side) on the lines indicate significant differences (Tukey's test of honestly significant difference - HSD). Source: The authors.

\section{Discussion}

Due to the significant neurovascular supply of the ear, larynx and nasopharynx regions, PPF is widely studied in several areas of Medicine (Hitotsumatsu et al., 1999; Evans, 2016). Imaging exams enabled a more detailed study of the anatomy of PPF and its relationship with other structures (Derinkuyu et al., 2017), these anatomical studies being essential for clinical practice. In an investigation on the different morphologies of PPF and the pterygopalatine ganglion, Khonsary et al. (2013) correlated some morphologies with a greater susceptibility to the occurrence of acute pain processes, as well as a lower sensitivity to neuralgia treatments. Tashi et al. (2016) concluded that PPF, in addition to being a passage of important anatomical structures, also functions as a conduit for the spread of infectious and neoplastic processes to deeper cervical planes, as an area of less resistance.

Morphometric evaluations allowed the study of new techniques for endoscopic surgical access in the PPF region (Fortes et al., 2008; Uehara et al., 2013; Elhadi et al., 2016), with three main accesses (ipsilateral endonasal transmaxillary, ipsilateral sublabial and contralateral endonasal transseptal transmaxillary transpterygoid approaches (Elhadi et al., 2016; Derinkuyu et al., 2017; Gibelli et al., 2019) used in neurological and respiratory tract surgeries. However, no study has used the CBCT, which is considered a high-resolution, three-dimensional technology that avoids overlap and allows accurate measurements, with a scale of approximately 1:1 (Hedge et al., 2018).

Considering the prevalence of posterior crossbite in the permanent dentition (Alhammadi, 2018), SARME is one of the treatment options commonly chosen, often performed by maxillofacial surgeons. According to Gurler et al. (2018), patients undergoing SARME may experience changes in the facial bones, such as increase in the volume of the nasal cavity, nasal volume and nasal vault. However, no study had reported possible changes in PPF. Therefore, the present study is the pioneer in evaluating this region, showing differences before and after surgery.

Despite previous investigations, there is still no consensus on the anatomy and limits of the PPF. Information about its height, length, volume and angulation may be important prior to surgical access in this region. They can delimit how much surgical instruments can move around in the region (Liu et al., 2017; Gibelli et al., 2019). Although it was expected that this region could be macerated during SARME, our findings showed that, in groups D + and D-, the postoperative measures were 
smaller $(\mathrm{p}>0.05)$ than the preoperative ones (table 1), indicating a reduction of PPF after SARME, regardless of whether or not there was PMD.

The decision on whether or not to perform PMD during SARME is still discussed among surgeons, especially about possible sequelae. For Medeiros et al., (2017) performing the PMD would imply in less areas of resistance to the trans-surgical movement. A systematic review (Carvalho et al., 2019) demonstrated the occurrence of postoperative complications in 29.95\% and $16.87 \%$ of patients not submitted to and submitted to PMD respectively (Verlinden et al., 2009; Hernandez-Alfaro et al., 2010; Williams et al., 2012; Pereira et al., 2018). In addition, greater possibilities for orthodontic complications were also found when PMD was not performed (22.99\% versus 9.27\%) (Zandi et al., 2016), and 86.67\% of cases of post-maxillary asymmetry were credited for not performing the PMD during SARME (Gurler et al., 2018).

The PFFV varied from 823.35 to $849.99 \mathrm{~mm}^{3}$ in $\mathrm{T} 1$ and from 822.53 to $830.82 \mathrm{~mm}^{3}$ in in T2, values similar to those described by Gibelli et al. (2019), who evaluated 100 helical CTs of Italian patients, using the same software (ITK-SNAPß) and found mean values from $871 \mathrm{~mm}^{3}$ to $878 \mathrm{~mm}^{3}$ on the right and left sides. The methodology for assessing volume in the two studies was quite similar. However, only the present investigation compared the results between patients who underwent disjunction (D+) or not (D-). When groups D+, D- and C were compared, the volumes of D+ were statistically lower on the right side. It could be speculated that manipulation during PMD could partially macerate PPF and that, after healing, its volume would decrease. There are no previous reports of the possible causes of differences in volume between the right and left sides. There is a hypothesis that the PPF are not identical and mirrored, since the skull is, in general, asymmetrical due to genetics or even muscle action over time.

The mean values of height varied from 16.49 to 16.38 in T1 and from 16.03 to $16.38 \mathrm{~mm}$ in T2. Tomaszewska et al. (2015), who evaluated helical CTs of 1500 individuals from Eastern Europe, found mean values between 29.9 mm and 32.5 $\mathrm{mm}$ on the right and left sides. However, the authors considered PPF as a passage between the lower orbital fissure and the palatal canal, extending to the limit of the opening of the greater palatine foramen. As with our methodology, VuksanovicBozaric et al., (2019) also considered the PPF to be a unique anatomical structure, separate from the greater palatine canal. The authors (Vuksanovic-Bozaric et al., 2019) evaluated 100 helical CT scans and found mean height values between 13.9 mm and $22.5 \mathrm{~mm}$.

No previous study has measured the length of the PPF. We found no statistically significant differences for these measures between the pre and postoperative periods. Perhaps this is due to the fact that the region in which the length was measured is the most superior of the PPF, while the area most affected by SARME is the most inferior portion. The control group had higher mean values on the left side, while the lowest values were observed in the D + group on the right side. For angular measurements, no previous study evaluated the pre- and postoperative differences in patients undergoing SARME. We found no statistically significant differences between pre, postoperative and control. Therefore, the null hypothesis was not rejected, indicating that SARME would not cause an angular alteration in the PFF, regardless of the technique employed.

As limitations, we highlight the need for experience with interpretation of CT images, since PPF is a small structure, whose limits and anatomical relationships are not yet fully established (Aoun et al., 2016; Derinkuyu et al., 2017; Icen \& Orhan, 2019). In addition, the anatomical variability of this structure must be considered (Khonsary et al., 2013; Derinkuyu et al., 2017; Icen \& Orhan, 2019). In summary, the morphometric analysis of PPF showed differences between the pre and postoperative groups and also a difference in volume when using techniques with or without PMD. The maxillofacial surgeon must be aware of these changes when performing SARME. This does not indicate or contraindicate the procedure, but it does reveal points that should be considered. Also, access via PPF for endoscopic procedures needs attention in patients who have already undergone SARME, since the dimensions of the structure may be altered, suggesting greater caution and less degree of 
movement of surgical instruments in the region.

\section{Conclusion}

In conclusion, when comparing these measures among groups $\mathrm{D}+, \mathrm{D}-$ and $\mathrm{C}$, for PPFV, on the right side, the values in group D+ presented significant differences when compared to D- and C. On the right side, there were statistically significant differences in the PPF volume, with lower values in patients in whom PMD was performed. These findings indicate a morphometric reduction of PPF after SARME, with differences when the disjunction is performed or not. Based on the data from our study, others can be performed, on the anatomy of the pterygopalatine fossa and adjacent structures, which despite being delicate and small structures, serve as passage for important nerves and blood vessels.

\section{References}

Alfieri, A., Jho, H. D., Schettino, R., \& Tschabitscher, M. (2003). Endoscopic endonasal approach to the pterygopalatine fossa: anatomic study. Neurosurgery, 52(2), 374-380.

Alhammadi, M. S., Halboub, E., Fayed, M. S., Labib, A., \& El-Saaidi, C. (2018). Global distribution of malocclusion traits: A systematic review. Dental press journal of orthodontics, 23(6), 40.e1-40.e10.

Ali Hasan, H., Khursheed Alam, M., Yusof, A., Matsuda, S., Shoumura, M., \& Osuga, N. (2016). Accuracy of Three Dimensional CT Craniofacial Measurements Using Mimics and InVesalius Software Programs. Journal of Hard Tissue Biology, 25(2), $219-224$.

Alves, N. et al. (2017). Nasolabial changes after two different approaches for surgically assisted rapid maxillary expansion. International Journal of Oral and Maxillofacial Surgery, v. 46, n. 9, p. 1088-1093.

Aoun, G., Nasseh, I., \& Sokhn, S. (2016). Radio-anatomical Study of the Greater Palatine Canal and the Pterygopalatine Fossa in a Lebanese Population: A Consideration for Maxillary Nerve Block. Journal of clinical imaging science, $6,35$.

Bailey, L. J., Haltiwanger, L. H., Blakey, G. H., \& Proffit, W. R. (2001). Who seeks surgical-orthodontic treatment: a current review. The International journal of adult orthodontics and orthognathic surgery, 16(4), 280-292.

Carvalho, P. H. A., Moura, L. B., Trento, G. S., Holzinger, D., Gabrielli, M. A. C., Gabrielli, M. F. R., \& Pereira Filho, V. A. (2019). Surgically assisted rapid maxillary expansion: a systematic review of complications. International Journal of Oral and Maxillofacial Surgery.

Codari, M., Zago, M., Guidugli, G. A., Pucciarelli, V., Tartaglia, G. M., Ottaviani, F., Righini, S., \& Sforza, C. (2016). The nasal septum deviation index (NSDI) based on CBCT data. Dento maxillo facial radiology, 45(2), 20150327.

Derinkuyu, B. E., Boyunaga, O., Oztunali, C., Alimli, A. G., \& Ucar, M. (2017). Pterygopalatine Fossa: Not a Mystery!. Canadian Association of Radiologists journal = Journal l'Association canadienne des radiologistes, 68(2), 122-130.

Elhadi, A. M., Zaidi, H. A., Yagmurlu, K., Ahmed, S., Rhoton, A. L., Jr, Nakaji, P., Preul, M. C., \& Little, A. S. (2016). Infraorbital nerve: a surgically relevant landmark for the pterygopalatine fossa, cavernous sinus, and anterolateral skull base in endoscopic transmaxillary approaches. Journal of neurosurgery, 125(6), 1460-1468.

Evans BT. (2016) Infratemporal and pterygopalatine fossae and temporomandibular joint. In: Standring S (ed). Gray's Anatomy: the anatomical basis of clinical practice, 41st edn, Elsevier, Amsterdam, pp 534-555.

Findık, Y., Baykul, T., \& Yazıcı, T. (2019). Nasal soft tissue changes after two different approaches for surgically assisted rapid maxillary expansion. International journal of oral and maxillofacial surgery, 48(7), 957-961.

Fortes FS, Sennes LU, Carrau RL, Brito R, Ribas GC, Yasuda A, Rodrigues AJ Jr, Snyderman CH, Kassam AB. (2008) Endoscopic anatomy of the pterygopalatine fossa and the transpterygoid approach: Development of a surgical instruction model. Laryngoscope;118(1):44-49. PMID: 17989582.

Gamer M. (2010). irr: Various coefficients of interrater reliability and agreement. http://cran. r-project. org/web/packages/irr/irr. pdf.

Gibelli, D., Cellina, M., Gibelli, S., Cappella, A., Panzeri, M. M., Oliva, A. G., Termine, G., Dolci, C., \& Sforza, C. (2019). Anatomy of the pterygopalatine fossa: an innovative metrical assessment based on 3D segmentation on head CT-scan. Surgical and radiologic anatomy : SRA, 41(5), 523-528.

Gurler, G. et al. (2018) Skeletal changes following surgically assisted rapid maxillary expansion (SARME). Eur Oral Res, Turkey, v.52, n.2, p.94-8.

Han, U. A., Kim, Y., \& Park, J. U. (2009). Three-dimensional finite element analysis of stress distribution and displacement of the maxilla following surgically assisted rapid maxillary expansion. Journal of cranio-maxillo-facial surgery : official publication of the European Association for Cranio-MaxilloFacial Surgery, 37(3), 145-154.

Hegde S, Ajila V, Kamath JS, Babu S, Pillai DS, Nair SM. (2018) Importance of cone-beam computed tomography in dentistry: An update SRM jornal of research in dental sciences. Vol 9; $4 ; 186-190$ 
Hernandez-Alfaro, F., Mareque Bueno, J., Diaz, A., \& Pagés, C. M. (2010). Minimally invasive surgically assisted rapid palatal expansion with limited approach under sedation: a report of 283 consecutive cases. Journal of oral and maxillofacial surgery : official journal of the American Association of Oral and Maxillofacial Surgeons, 68(9), 2154-2158.

Hitotsumatsu T, Matsushima T, Rhoton AL. (1999). Surgical anatomy of the midface and the midline skull base. Oper Tech Neurosurg ;2(4):160-180.

Icen, M., \& Orhan, K. (2019). Cone-beam computed tomography evaluation of the pterygomaxillary fissure and pterygopalatine fossa using 3D rendering programs. Surgical and radiologic anatomy : SRA, 41(5), 513-522.

Kayalar, E., Schauseil, M., Hellak, A., Emekli, U., Firatl1, S., \& Korbmacher-Steiner, H. (2019). Nasal soft- and hard-tissue changes following tooth-borne and hybrid surgically assisted rapid maxillary expansion: A randomized clinical cone-beam computed tomography study. Journal of cranio-maxillo-facial surgery : official publication of the European Association for Cranio-Maxillo-Facial Surgery, 47(8), 1190-1197.

Khonsary, S. A., Ma, Q., Villablanca, P., Emerson, J., \& Malkasian, D. (2013). Clinical functional anatomy of the pterygopalatine ganglion, cephalgia and related dysautonomias: A review. Surgical neurology international, 4(Suppl 6), S422-S428.

Kish, L. (1995). Survey Sampling. New York: John Wiley and Sons.

Landis JR, \& Koch GG. (1977). The measurement of observer agreement for categorical data. biometrics, 159-174.

Liu, M. C., Yin, X. R., Zhang, Y. S., Yang, W., Zhang, H. W., Duan, H. B., Liu, J. M., Cheng, K. L., \& Li, Y. Q. (2017). Computed Tomography Research: Relative Anatomy of Caldwell-Luc Approach in Pterygopalatine Fossa Surgery. The Journal of craniofacial surgery, 28(6), 1537-1540.

Medeiros JR, Ferraro Bezerra M, Costa FWG, Bezerra TPP, de Araújo Alencar CR, Studart Soares EC. (2017) Does pterygomaxillary disjunction in surgically assisted rapid maxillary expansion influence upper airway volume? A prospective study using Dolphin Imaging 3D. Int J Oral Maxillofac Surg. Sep;46(9):1094-1101. doi: 10.1016/j.ijom.2017.04.010. Epub 2017 May 15. PMID: 28521967.

Pereira, M. D., Koga, A. F., Prado, G., \& Ferreira, L. M. (2018). Complications From Surgically Assisted Rapid Maxillary Expansion With HAAS and HYRAX Expanders. The Journal of craniofacial surgery, 29(2), 275-278.

R Core Team. (2020). R: a language and environment for statistical computing. Vienna, AT: R Foundation for Statistical Computing.

Sokucu, O., Kosger, H. H., Bicakci, A. A., \& Babacan, H. (2009). Stability in dental changes in RME and SARME: a 2-year follow-up. The Angle orthodontist, 79(2), 207-213.

Tashi, S., Purohit, B. S., Becker, M., \& Mundada, P. (2016). The pterygopalatine fossa: imaging anatomy, communications, and pathology revisited. Insights into imaging, 7(4), 589-599.

Tomaszewska, I.M., Kmiotek, E.K., Pena, I.Z. et al. (2015) Computed tomography morphometric analysis of the greater palatine canal: a study of 1,500 head CT scans and a systematic review of literature. Anat Sci Int 90, 287-297.

Uehara M, Tominaga K, Asahina I. (2013) Surgical approach to the pterygopalatine fossa -comparison between anterior approach and lateral approach. J Craniofac Surg;24(2);536-539.

Verlinden, C. R., Gooris, P. G., \& Becking, A. G. (2011). Complications in transpalatal distraction osteogenesis: a retrospective clinical study. Journal of oral and maxillofacial surgery: official journal of the American Association of Oral and Maxillofacial Surgeons, 69(3), 899-905.

Von Elm E, Altman DG, Egger M, Pocock SJ, Gøtzsche PC, Vandenbroucke JP. (2008) STROBE initiative. The strengthening the reporting of observational studies in epidemiology (STROBE) statement: guidelines for reporting observational studies. J Clin Epidemiol:61:344-349.

Vuksanovic-Bozaric A, Vukcevic B, Abramovic M, Vukcevic N, Popovic N, Radunovic M. (2019) The pterygopalatine fossa: morphometric CT study with clinical implications. Surg Radiol Anat. Feb;41(2):161-168. doi: 10.1007/s00276-018-2136-8. Epub 2018 Nov 23. PMID: 30470877.

Wickham H. (2016). ggplot2: elegant graphics for data analysis. springer.

Williams, B. J., Currimbhoy, S., Silva, A., \& O'Ryan, F. S. (2012). Complications following surgically assisted rapid palatal expansion: a retrospective cohort study. Journal of oral and maxillofacial surgery : official journal of the American Association of Oral and Maxillofacial Surgeons, 70(10), $2394-2402$.

Yushkevich, P. A., Piven, J., Hazlett, H. C., Smith, R. G., Ho, S., Gee, J. C., \& Gerig, G. (2006). User-guided 3D active contour segmentation of anatomical structures: significantly improved efficiency and reliability. NeuroImage, 31(3), 1116-1128.

Zandi, M., Miresmaeili, A., Heidari, A., \& Lamei, A. (2016). The necessity of pterygomaxillary disjunction in surgically assisted rapid maxillary expansion: A short-term, double-blind, historical controlled clinical trial. Journal of cranio-maxillo-facial surgery : official publication of the European Association for Cranio-Maxillo-Facial Surgery, 44(9), 1181-1186. 